НАУКОВИЙ ВІСНИК

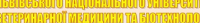

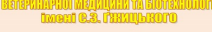

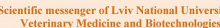
(20)

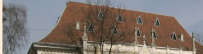
11 IIMMU

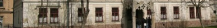
СЕРЯ: ХАРчОВі ТЕХНолоО⿴囗 ERRIS: FOOD TECHNOL Том 23 № 9 2021
Науковий вісник Аьвівського національного університету ветеринарної медицини та біотехнодогій імені С.3. Гжицького. Серія: Харчові технології

\section{Scientific Messenger of Lviv National University} of Veterinary Medicine and Biotechnologies.

Series: Food Technologies https://nvlvet.com.ua/index.php/food

UDC 664.647.016

\title{
Structural and mechanical parameters of the dough semi-finished product for culinary flour products
}

\author{
M. Perepelytsia \\ Kyiv National University of Trade and Economics, Kyiv, Ukraine
}

Article info

Received 06.01.2021

Received in revised form 08.02 .2021

Accepted 09.02.2021

Kyiv National University of Trade and Economics Kyoto Str., 19, Kiev, 02156, Ukraine.

Tel.: +38-044-531-47-41

E-mail:vokd@knute.edu.ua
Perepelytsia, M. (2021). Structural and mechanical parameters of the dough semi-finished product for culinary flour products. Scientific Messenger of Lviv National University of Veterinary Medicine and Biotechnologies. Series: Food Technologies, 23(95), 7-12. doi: 10.32718/nvlvetf9502

Taking into account the need to improve existing, optimize and create new technologies for flour culinary products, there is a need to use non-traditional raw materials for the design of flour culinary products of high nutritional value. The prescription composition of these products is adjustable, which allows you to create foods that meet the traditional requirements for consumer properties and modern requirements of nutrition. The article investigates the structural and mechanical parameters of the dough semi-finished product for flour culinary products. The influence of protein-fat additive and carrageenan on structural and mechanical properties that characterize the deformation behavior of the dough semi-finished product under stress conditions, the main indicators of which at applied force are the ultimate stress, plastic viscosity, modulus of elasticity. In order to develop the technology of flour culinary products using BJD ESO and carrageenan, it is important to determine the rational concentration of additives and the method of their introduction into the dough semi-finished product. For the manufacture of model dough compositions were added BJD ESO was added in an amount of from 5 to $30 \%$ and carrageenan from 0.5 to $3.0 \%$ instead of wheat flour. According to the results of research, the influence of BJD ESO and carrageenan on the structural and mechanical properties of the dough semi-finished product was established. When the concentration of BJD ESO increases from 5 to $30 \%$, the value of plastic viscosity decreases by $3.2-67.3 \%$, respectively. Therefore, to improve the structural and mechanical properties in the model test compositions added carginan. When the concentration of carrageenan increases from 0.5 to $3.0 \%$, the value of the plastic viscosity of fresh dough increases by $0.9-18.4 \%$, respectively. At the concentration of carrageenan $1.0 \%$, the value of the indicator is close to the control $\left(7.06 \mathrm{PA} \times \mathrm{S}^{*} 10^{8}\right)$ and is 7.12 and $7.27 \mathrm{PA} \times \mathrm{S}^{*} 10^{8}$. Therefore, using the methods of mathematical modeling taking into account the structural and mechanical properties, determined the rational concentrations of the functional composition for the test semi-finished product - $11 \%$ (1.0\% carrageenan and $10.0 \%$ BJD ESO, which can be used in the technology for new types of dough semi-finished products for flour culinary products.

Key words: model test compositions, shear stress, modulus of elasticity, modulus of elasticity, plastic viscosity.

\section{Структурно-механічні показники тістового напівфабрикату борошняних кулінарних виробів}

\author{
М. П. Перепелиця
}

Київський національний торговельно-економічний університет, м. Київ, Украӥна

3 урахуванням необхідності удосконалення існуючих, оптимізації та створення нових технологій борошняних кулінарних виробів виникає необхідність використання нетрадиційної сировини для проектування борошняних кулінарних виробів підвищеної харчової цінності. Рецептурний склад зазначених виробів піддається регулюванню, щзо дозволяє створювати харчові продукти, які відповідають традииійним вимогам до споживних властивостей і сучасним вимогам нутричіологї. У статті досліджено структурно-механічні показники тістового напівфабрикату для борочняних кулінарних виробів. Проаналізовано вплив білково-жирової 
добавки та карагінану на структурно-механічні властивості, щзо характеризують деформаційну поведінку тістового напівфабрикату в умовах напруги, основними показниками якого при прикладені сили є гранична напруга, пластична в 'язкість, модуль пружності еластичності. 3 метою розробки технології борошняних кулінарних виробів з використанням БЖД ЕСО та карагінану важливо визначити раціональну концентрацію добавок та спосіб їх введення у тістовий напівфабрикат. Для виготовлення модельних тістових композичій додавали БЖД ЕСО у кількості від 5 до 30 \% та карагінан від 0,5 до 3,0 \% замість борошна пшеничного. Вимірювання показників здійснювали через 40 хв після замімування тіста, протягом иього часу, біохімічні та фізико-хімічні процеси, щзо формують структуру тіста відбуваються з найбільшою швидкістю. За результатами досліджень встановлено вплив білково-жирової добавки ЕСО та карагінану на структурно-механічні властивості тістового напівфабрикату. При збільшенні концентрації БЖД ЕСО від 5 до 30 \% значення пластичної в'язкості знижується відповідно на 3,2-67,3 \%. Тому для покращення структурно-механічних властивостей у модельні тістові композищіі додали каргінан. При збільщенні концентрації карагінану від 0,5 до 3,0\% значення пластичної в 'язкості прісного тіста підвишується відповідно на 0,9-18,4\%. При иьому за концентрації

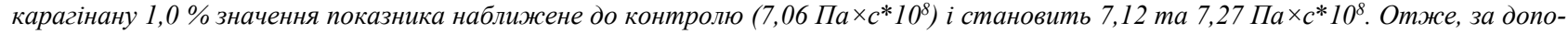
могою методів математичного моделювання з урахуванням структурно-механічних властивостей, визначено раціональні концентрації функціональної композичї для тістового напівфабрикату - 11 \% (1,0\% карагінану та 10,0\% БЖД ЕСО), які можуть бути використані в технологї нових видів тістових напівфабрикатів для борошняних кулінарних виробів.

Ключові слова: модельні тістові композиціі, гранична напруга зсуву, модуль пружності, модуль еластичності, пластична в 'язкість.

\section{Вступ}

Харчування - одна з основних проблем, рішення якої складає предмет постійного піклування людства. Важливим фактором у покращенні якості та тривалості життя є раціональне харчування. Тому необхідно оптимізувати поживну цінність раціону харчування людини, 3 урахуванням рекомендованих сучасних фізіологічних норм споживання, що не може бути досягнене лише збільшенням споживання традиційних продуктів харчування і вимагає нових наукових і технологічних підходів та рішень (Mazaraki, 2012; Aguilar-Toaláa et al., 2018; Kaprelyants et al., 2019; Lebedenko et al., 2019; Kapustjan et al., 2020).

Борошняні кулінарні вироби належать до продуктів широкого вжитку, проте їхній склад переобтяжений вуглеводами (переважно крохмалем), що не задовольняє основних вимог раціонального харчування (Mazaraki, 2012).

В останні роки спостерігається потреба зниження рівня споживання пшеничного борошна та підвищення біологічної цінності хлібобулочних та борошняних виробів для покращення здоров'я людини із використанням альтернативних видів борошна: житнього, гречаного, рисового, мигдального вісяного, полб'яного, пшенично-спельтового, конопляного, соєвого тощо (Iorgachova et al., 2018; Medvedeva, 2018; Demichkovs'ka, 2019; Moeini et al., 2020; Iorgacheva \& Sokolova, 2020; Zhygunov et al., 2020; Zaparenko et al., 2020; Judina et al., 2020).

Одним 3 традиційних напрямів вдосконалення технологій борошняних кулінарних виробів $є$ підвищення їх харчової цінності за рахунок збагачення білковими добавками, зокрема соєю (Milatovich \& Mondelli, 1990; Beletska et al., 2020). За амінокислотним складом протеїн зернобобових наближається до тваринних білків. Водночас харчову цінність білків значно зменшують природні біологічно-активні речовини - інгібітори: трипсин, протеїнази, гемаглютини, фітоестрогени, алергени, олігоцукри, сапоніни, фітинова кислота, ліпоксигеназа тощо, які ускладнюють травлення. Нейтралізувати негативний вплив інгібіторів можливо за допомогою технології мікронізації зерна, в основу якої покладено дію короткочасного світлового потоку 3 оптимізованою енергетичною експозицією (Mazaraki, 2012).

Технологія виробництва мікронізованого зерна сприяє трансформації харчових речовин у форми, що можуть засвоюватися, і дозволяє отримати продукти 3 високим вмістом мінеральних речовин (кальцію, заліза, магнію, селену), вітамінів Е, С, групи В, незамінних амінокислот, поліненасичених жирних кислот, харчових волокон. За цією технологію виготовлено добавку білково-жирову ЕСО (ДБЖ ЕСО). Оскільки, БЖД ЕСО має низький вміст клейковини, що погіршує структурно-механічні характеристики тістового напівфабрикату, то потребує застосування структуроутворювачів. Карагінан є перспективним структуроутворювачем для використання в рецептурах прісного тіста. У дослідженнях використаний карагінан (суміш йота- і капа-карагінану), отриманий з чорноморської червоної водорості, у вигляді світло-кремового порошку з вологістю 9-12\% і розміром частинок - від 0,25 до 1 мм (Mazaraki, 2012; Perepelicja, 2019).

Метою роботи є визначення впливу дієтичних добавок, які вносяться в модельні тістові композиції на структурно-механічні властивості тістового напівфабрикату.

Для досягнення поставленої мети необхідно вирішити наступні завдання:

- визначити структурно-механічні властивості тістового напівфабрикату;

-дослідити вплив дієтичних добавок (БЖД ЕСО, карагінан) на структурно-механічні властивості тістового напівфабрикату;

-визначити раціональну концентрацію та обгрунтувати технологію використання БЖД ЕСО та карагінану;

-провести розрахунок коплексного показника якості тістового напівфабрикату.

\section{Матеріал і методи досліджень}

Експериментальні дослідження виконувалися на базі науково-дослідних лабораторій кафедри технології і організації ресторанного господарства Київського національного торговельно-економічного університету та Харківського державного університету харчування та торгівлі. 
Структурно-механічні властивості тістового напівфабрикату визначали на плоскопаралельному еластопластометрі Толстого, пенетрометрі “Labor" 3 подальшим математичним моделювання у табличному редакторі Excel (Goral'chuk et al., 2006).

Визначення раціональної концентрації дієтичних добавок здійснювалося у два етапи: 1) обрано фактори оптимізації та визначено межі їх змін; 2) за методом “довільного плану експерименту” розраховано математичну модель залежності комплексного показника якості від вмісту добавки білково-жирової ЕСО, карагінану харчового. Для побудови математичних моделей обрані поліноми. Для визначення кількості поліномів застосувався метод “вузлів решітки" (Hartman et al., 1977).

\section{Результати та їх обговорення}

Вплив добавок, які вносяться в модельні тістові композиції, в тому числі на основі пшеничного борошна, не обмежується лише збагаченням їх інгредієнтами, що підвищують харчову цінність виробів, застосування цих добавок впливає на біополімери борошна, змінюючи реологічні властивості тіста і якість виробів в цілому.

Тісто є полідисперсною колоїдною системою, що являє собою пружно-пластичне тіло. Така особливість уможливлює досліджувати його за багатьма показниками, але саме структурно-механічні властивості піддаються математичному опису. Це дає змогу з високою точністю прогнозувати кінцеву якість готової продукції й за потреби корегувати їі рецептуру (Krivoruchko, 2018).

Структура тіста, що утворюється з борошна різних зернових та зернобобових культур, визначається кількісним і якісним складом основних полімерних сполук (крохмалю, білків, клітковини), наявністю низькомолекулярних, гідро- і олеофільних сполук. Полімери борошняної сировини і вода утворюють основу колоїдної структури тіста. В процесі утворення тіста гідратовані білки гліадин та глютеліну відіграють головну роль, визначаючи подальші процеси форму-

\section{Таблиця 1}

Структурно-механічні показники модельних тістових композицій

\begin{tabular}{lccccccc}
\hline \multicolumn{1}{c}{ Показник } & \multirow{2}{*}{ Контроль } & \multicolumn{5}{c}{ Найменування зразків } \\
\cline { 3 - 7 } & & MTК1 & MTК2 & МТК3 & МТК4 & МТК5 & МТК6 \\
\hline Модуль пружності, (Па) & 49050,0 & 49445,6 & 50454,7 & 53110,2 & 55905,4 & 57046,4 & 57146,4 \\
Модуль еластичності, (Па) & 8378,6 & 8446,2 & 8618,6 & 9072,2 & 9549,7 & 9862,4 & 9946,4 \\
Пластична в'язкість, Па×с*10 $10^{8}$ & 7,06 & 7,12 & 7,27 & 7,65 & 8,05 & 8,3 & 8,36 \\
\hline
\end{tabular}

Примітка: Контроль - тісто прісне; МТК 1 - БЖД ЕСО $10 \%$ та карагінан 0,5 \%; МТК 2 - БЖД ЕСО10 \% та карагінан 1,0\%; МТК 3 - БЖД ЕСО $10 \%$ та карагінан 1,5 \%; МТК 4 - БЖД ЕСО $10 \%$ та карагінан 2,0 \%; МТК 5 - БЖД ЕСО 10 \% та карагінан 2,5 \%; МТК 6 - БЖД ЕСО 10 \% та карагінан 3,0 \%

При цьому за концентрації карагінану 0,5 і 1,0\% у модельних тістових композиціях значення модуля пружності зразків наближене до контролю (49050 Па) і становить 49445,6 Па та 50454,7 Па. У той же час показник модуля еластичності модельних тістових композицій підвищується при збільшенні концентра- вання тіста (Perepelicja, 2019; Bayramov \& Nabiev, 2019).

3 метою розробки технології борошняних кулінарних виробів з використанням БЖД ЕСО та карагінану важливо визначити раціональну концентрацію добавок та спосіб їх введення у тістовий напівфабрикат. Для виготовлення модельних тістових композицій БЖД ЕСО додавали у кількості від 5 до 30 \% та карагінан від 0,5 до 3,0 \% замість борошна пшеничного. Для досліджень використовували борошно вищого сорту. В якості контролю використовували прісне тісто виготовлене за традиційною технологією. Контролем слугували: тістовий напівфабрикат для вареників та пельменів, виготовлені за традиційною рецептурою № 1107, 1115 (Zdobnov et al., 1998). Вимірювання показників здійснювали через 40 хв після замішування тіста, протягом цього часу, біохімічні та фізико-хімічні процеси, що формують структуру тіста відбуваються з найбільшою швидкістю.

На якість тістового напівфабрикату впливають такі структурно-механічні властивості, що характеризують деформаційну поведінку тістового напівфабрикату в умовах напруги, основними показниками якого при прикладені сили є гранична напруга, пластична в'язкість, модуль пружності еластичності і т.д. (Goral'chuk et al., 2006).

Модуль пружності $\left(\mathrm{G}_{n p}\right)$ характеризує здатність тіла чинити опір пропорційно його деформації і $є$ мірою пружності, тобто спроможності тіла повертатися до початкового стану після припинення дії напруження. Модуль еластичності $\left(\mathrm{G}_{e л}\right)$ характеризує зникнення деформації в тілі з часом після зняття напруження i при підвищенні його значення свідчить про зменшення часу, необхідного для зникнення деформації тіла (Goral'chuk et al., 2006).

Встановлено, що при збільшенні концентрації БЖД ЕСО від 5 до 30 \% та карагінагу з 0,5 до 3,0 \% в модельних тістових композиціях значення модуля пружності зростає відповідно з 0,8 до 16,6 \% у порівнянні з контролем, що свідчить про підвищення здатності тістового напівфабрикату чинити опір пропорційно його деформації, тобто про зміцнення структури тіста (табл. 1). 
коджає переміщенню шарів відповідно текучого й пружного матеріалу (Goral'chuk et al., 2006).

При збільшенні концентрації БЖД ЕСО від 5 до 30\% значення пластичної в'язкості знижується відповідно на 3,2-67,3 \%. За структурно-механічними, органолептичними характеристиками та показниками хімічного складу, раціональна концентрація БЖД ЕСО становить $10 \%$, за якої показник пластичної в'язкості наближений до контролю $\left(7,06\right.$ Па $\left.\times \mathrm{c}^{*} 10^{8}\right)$ i становить 6,81 Па $\times \mathrm{c}^{*} 10^{8} .3$ метою отримання структурно-механічних показників, близьких до показників традиційного прісного тіста, використано карагінан. Отримано значення пластичної в'язкості дослідних зразків модельних тістових композицій за різної концентрації карагінану (табл. 1, рис. 1).

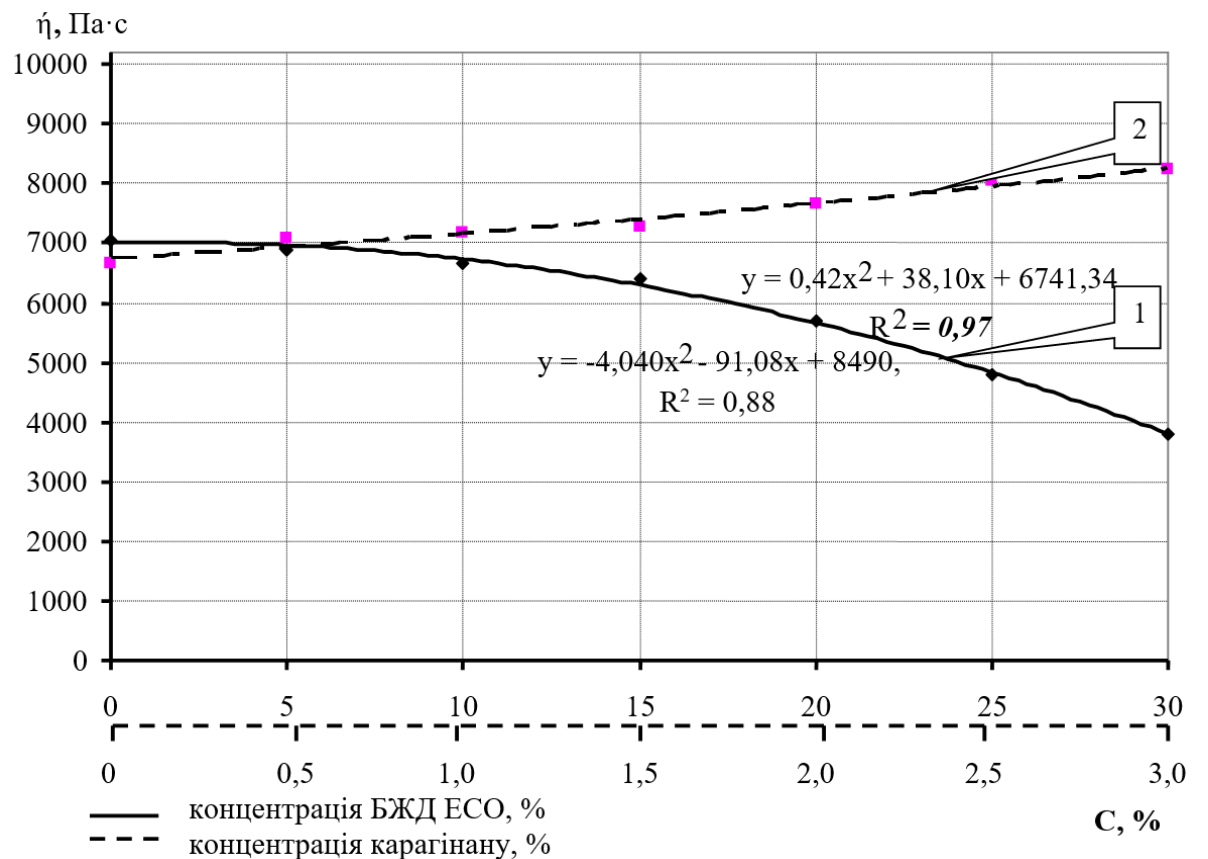

Рис. 1. Пластична в’язкість тістового напівфабрикату за різних концентрацій: 1 - БЖД ЕСО та 2 - карагінану

Залежність між вмістом карагінану і даним показником є прямою. При збільшенні концентрації карагінану від 0,5 до 3,0 \% значення пластичної в'язкості прісного тіста підвищується відповідно на $0,9-$ 18,4 \%. При цьому за концентрації карагінану 1,0 \% значення показника наближене до контролю $\left(7,06\right.$ Па× $\left.{ }^{*} 10^{8}\right)$ і становить 7,12 та 7,27 Па× $* 10^{8}$ Підвищення пластичних властивостей тістового напівфабрикату обумовлене структуроутворюючими вла- стивостями карагінану, а саме особливістю взаємодіяти з білками борошна пшеничного, утворюючи більш міцну просторову сітку.

3 метою аналізу структурно-механічних властивостей тістового напівфабрикату важливо дослідити граничну напругу зсуву $\left(\tau_{0}\right)$ - мінімальне дотичне напруження, яке необхідне для здійснення зсуву призводить до незворотної деформації (табл. 2).

\section{Таблиця 2}

Гранична напруга зсуву модельних тістових композицій

\begin{tabular}{cccccccc}
\hline \multirow{2}{*}{ Показник } & \multirow{2}{*}{ Контроль } & \multicolumn{5}{c}{ Найменування зразків } \\
\cline { 3 - 7 } & & МТК1 & МТК2 & МТК3 & МТК4 & МТК5 & МТК6 \\
\hline Гранична напруга зсуву (ГН3), Па & 1303,2 & 1378,7 & 1419,0 & 1482,8 & 1550,9 & 1623,9 & 1702,1 \\
у \% до контролю & 100 & 105,8 & 108,8 & 113,8 & 119,0 & 124,6 & 130,6 \\
\hline
\end{tabular}

Примітка: Контроль - тісто прісне; МТК 1 - БЖД ЕСО $10 \%$ та карагінан 0,5\%; МТК 2 - БЖД ЕСО10 \% та карагінан 1,0\%; МТК 3 - БЖД ЕСО $10 \%$ та карагінан 1,5 \%; МТК 4 - БЖД ЕСО $10 \%$ та карагінан 2,0 \%; МТК 5 - БЖД ЕСО 10 \% та карагінан 2,5 \%; МТК 6 - БЖД ЕСО 10 \% та карагінан 3,0 \%

Встановлено, що при збільшенні концентрації БЖД ЕСО від 5 до 30 \% та карагінагу з 0,5 до 3,0 \% в модельних тістових композиціях значення показника граничної напруги зсуву збільшується з 5,8 до 30,6 \%, що пояснюється збільшенням вмісту міцнозв'язаної вологи. При цьому за концентрації карагінану 0,5 i $1,0 \%$ значення показника наближене до контролю (1303,2 Па) і становить 1378,7 Па та 1419,0 Па відпо- відно. Доведено, що при збільшенні карагінану від 1,5 до $3,0 \%$ не дозволяє отримати тістовий напівфабрикат зі структурними характеристиками, близькими до контролю.

При дослідженні хімічного складу тістового напівфабрикату встановлено, що вміст білка у ньому зріс на 26,3 \%; ліпідів - на 97,1\%; вуглеводів: у т.ч. монота дисахаридів - на 66,8 \%, харчових волокон - на 
$22,0 \%$, разом 3 тим зменшився вміст крохмалю - на $10,3 \%$, збільшився загальний вміст мінеральних речовин (золи) на $21 \%$ у порівняно з контролем.

Математична обробка експериментальних даних дозволила отримати рівняння регресії, яке описує однофакторний простір досліджуваної залежності оцінки показників якості модельних тістових композицій за різних концентрацій БЖД ЕСО та карагінану (рис. 2).

Після розрахунків отримаємо рівняння регресії, що показує залежність комплексної якості для тістового напівфабрикату від кількості БЖД ЕСО та карагінану (1)

$$
\begin{aligned}
& Z=-6,27 y^{2}-0,48 x^{2}-5,40 y+6,41 x+0,99 x y+75,48 \\
& \text { де: } Z \text { - комплексний показник якості; } \\
& \text { x - концентрація БЖД ЕСО, \%; }
\end{aligned}
$$

У - концентрація карагінану, \%.

Математичні моделі залежності комплексного показника якості від вмісту дієтичних добавок сильно відрізняються, зокрема, якщо область раціональних значень добавок (КПЯ >90) у тістовому напівфабрикаті досить вузька концентрації БЖД ЕСО від 7$11,5 \%$, карагінану від 0,6-1,8\%. Тому, враховуючи вищезгадане, підбір оптимальних концентрацій дієтичних добавок в модельних тістових композицій здійснено математичним аналізом поверхні відгуку або рівнянням 3 подальшим закругленням результатів для спрощення дозування на виробництві. В оптимальній області концентрації добавок у модельних тістових композицій різниця у значенні КПЯ лежить в межах статистичної похибки.

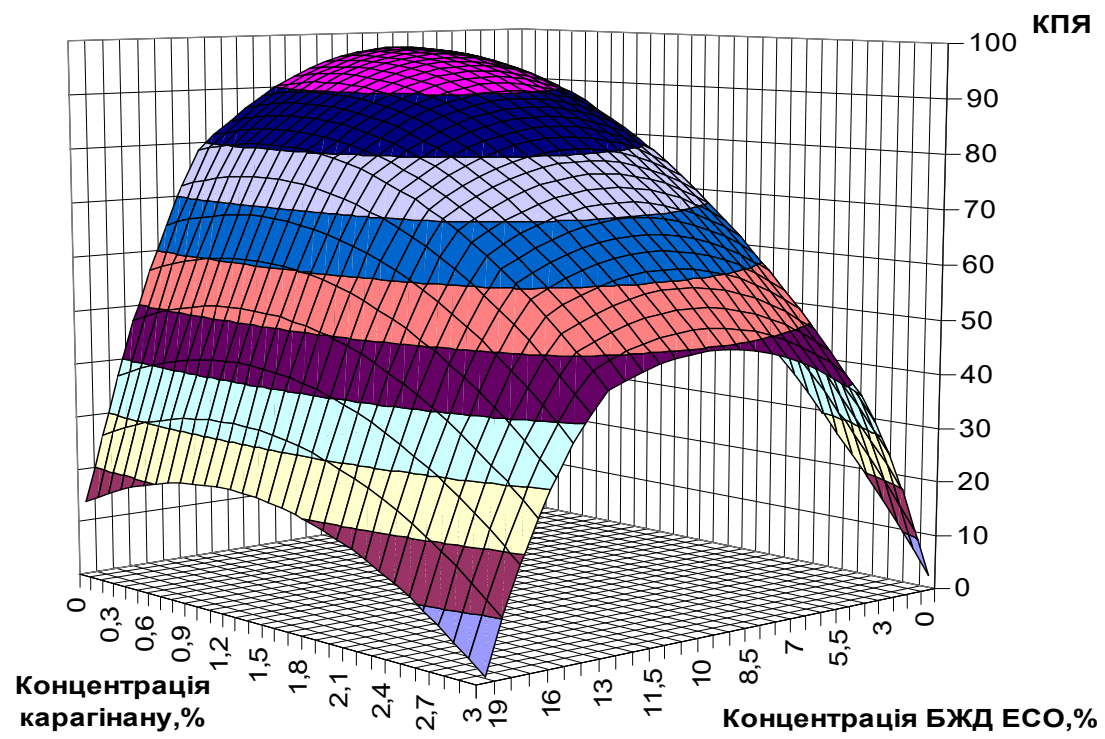

Рис. 2. Комплексний показник якості тістового напівфабрикату за різних концентрацій БЖД ЕСО та карагінану

Отже, за допомогою методів математичного моделювання 3 урахуванням структурно-механічних властивостей, визначено раціональні концентрації функціональної композиції для тістового напівфабрикату $11 \%$ (1,0 \% карагінану та 10,0 \% БЖД ЕСО).

\section{Висновки}

За результатами досліджень встановлено вплив білково-жирової добавки ЕСО та карагінану на структурно-механічні властивості тістового напівфабрикату. При збільшенні концентрації БЖД ЕСО від 5 до 30 \% значення пластичної в'язкості знижується відповідно на 3,2-67,3 \%. Тому для покращення структурно-механічних властивостей у модельні тістові композиції додали каргінан. При збільшенні концентрації карагінану від 0,5 до 3,0 \% значення пластичної в'язкості прісного тіста підвищується відповідно на 0,9-18,4 \%. При цьому за концентрації карагінану $1,0 \%$ значення показника наближене до контролю $\left(7,06\right.$ Па $\left.\times \mathrm{c}^{*} 10^{8}\right)$ і становить 7,12 та 7,27 Па $\times \mathrm{c} * 10^{8}$.

Таким чином, у результаті проведення досліджень обгрунтовано доцільність використання модельних тістових композицій з концентрацією БЖД ЕСО 10 \%, карагінану 1,0% для тістового напівфабрикату, який за структурно-механічними характеристиками наближається до контролю і може бути використаний в технології для нових видів тістових напівфабрикатів для борошняних кулінарних виробів.

\section{References}

Aguilar-Toaláa, J. E., Garcia-Varelab, R., Garciac, H. S., Mata-Harod, V., González-Córdovaa, A. F., VallejoCordobaa, B., \& Hernández-Mendoza, A. (2018) Postbiotics: An evolving term within the functional foods field. Trends in Food Science \& Technology, 75, 105-114. doi: 10.1016/j.tifs.2018.03.009.

Bayramov, E., \& Nabiev, A. (2019). Fiziko-himichni procesi, shho rozvivajut'sja $\mathrm{v}$ masi komponentiv tista pri jogo vigotovlenni. Food Science and Technology, 13(3), 10-17. doi: 10.15673/fst.v13i3.1451.

Beletska, Y., Plotnikova, R., Bakirov, M., \& Vereshchynskyi, O. (2020). Rozrobka tehnologii boroshna soi zbagachenogo jodom. Food Science and Technology, 14(2), 87-95. doi: 10.15673/fst.v14i2.1487. 
Demichkovs'ka, M. P. (2019) Tehnologija lavashu z vikoristannjam netradicijnoyi syrovyny. Praci Tavrijs'kogo derzhavnogo agrotehnologichnogo universitetu, 1(19), 217-226. doi: 10.31388/20780877-19-1-217-225.

Goral'chuk, A. B., Pyvovarov, P. P., Grynchenko, O. O. ta in. (2006). Reologichni metody doslidzhennja syrovyny i harchovyh produktiv ta avtomatyzacija rozrahunkiv reologichnyh harakterystyk: navch. posib. Harkiv: Harkiv. derzh. un-t harchuvannja ta torgivli (in Ukrainian).

Hartman, K., Leckij, Je., \& Shiffer, V. (1977) Planirovanie jeksperementa $\mathrm{v}$ issledovanii tehnologicheskih processov. M.: Izdatel'stvo "Mir" (in Russian).

Iorgacheva, K., \& Sokolova, N. (2020). Potencial boroshna $\mathrm{z}$ konopljanogo shrotu jak recepturnogo ingredienta hlibobulochnih virobiv znizhenoï vologosti. Food Science and Technology, 14(3), 44 53. doi: 10.15673/fst.v14i3.1789.

Iorgachova, K., Makarova, O., Kotuzaki, O., \& Avetisian, K. (2018). The use of glucan-containing grain materials in the technology of foam-like pastries. Food Science and Technology, 12(3), 81-87. doi: $10.15673 /$ fst.v12i3.1042.

Judina, T., Romanenko, R., \& Bezruchenko, O. (2020). Pidvyshhennja tehnologichnogo potencialu agljutenovoi boroshnjanoi syrovyny. Tovary i rynky, 4(36), 93-103. doi: 10.31617/tr.knute.2020(36)09.

Kaprelyants, L., Yegorova, A., Trufkati, L., \& Pozhitkova, L. (2019). Funkcional'ni produkty harchuvannja: perspektyvy v Ukraini. Food Science and Technology, 13(2), 15-23. doi: 10.15673/fst.v13i2.1382.

Kapustian, A., Cherno, N., \& Lebedenko, T. (2020). Functional wheat bread with calcium chelate complexes. Scientific Messenger of LNU of Veterinary Medicine and Biotechnologies. Series: Food Technologies, 22(93), 31-38. doi: 10.32718/nvlvetf9306.

Krivoruchko, M. (2018). Pruzhno-v'jazkisni harakterystyky tistovyh kompozicij z kokosovoju klitkovynoju. Tovary i rynky, 10(27), 99-108. doi: $10.31617 /$ tr.knute.

Lebedenko, T., Korkach, H., Kozhevnikova, V., \& Novichkova, T. (2019). Sposobi reguljuvannja fizichnih vlastivostej tista $\mathrm{z}$ vikoristannjam fitoekstraktiv. Food Science and Technology, 12(4), 52-62. doi: 10.15673/fst.v12i4.1182.

Mazaraki, A. A. (2012). Tekhnolohiia produktiv funktsionalnoho pryznachennia: monohrafiia. K.: Kyiv. nats. torh.-ekon. un-t (in Ukrainian).

Medvedeva, A. (2018). Tehnologija bezgljutenovyh bulochnyh vyrobiv. Tovary i rynki, 4(28), 115-123. doi: 10.31617/tr.knute.2018(28)11.

Milatovich, L., \& Mondelli, G. (1990). La tecnologia della pasta alimentare. Pinerolo: Chiriotti (in Utalian).

Moeini, A., Masoud Shafafi Zenoozian, M. S., Karazhiyan, H., Rad, A. H., \& Nia, A. P. (2020). Harakteristika tista, vigotovlenogo iz riznih vidiv pshonjanogo boroshna dlja virobnictva hliba. Food Science and Technology, 14(4), 78-87. doi: 10.15673/fst.v14i4.1894 (in Ukrainian).

Perepelicja, M. P. (2019). Jakist' klejkovyny tistovogo napivfabrykatu dlja boroshnjanyh kulinarnyh vyrobiv. Visnyk Harkivs'kogo nacional'nogo tehnichnogo universitetu sil's'kogo gospodarstva im. P. Vasylenka, 207, 206-215 (in Ukrainian).

Zaparenko, A., Didenko, S., Holyk, O., \& Goloventsov, Y. (2020). Doslidzhennja tehnologichnih vlastivostej boroshna polb'janogo. Food Science and Technology, 14(2), 111-119. doi: 10.15673/fst.v14i2.1717 (in Ukrainian).

Zdobnov, A. I., Cyganenko, V. A., \& Peresichnyj, M. I. (1998). Sbornik receptur bljud i kulinarnyh izdelij dlja predprijatij obshhestvennogo pitanija. K., A.S.K. (in Russian).

Zhygunov, D., Barkovska, Y., Yehorshyn, Y., Zhyhunova, H., \& Barikian, K. (2020). Pshenychno-spel'tove boroshno tiyp $600 \mathrm{iz}$ polipshenymy hlybopekars'kymy vlastyvostjamy. Food Science and Technology, 14(1), 53-62. doi: 10.15673/fst.v14i1.1646 (in Ukrainian). 